Bentham open
CrossMark
Content list available at: www.benthamopen.com/TOCIEJ/
DOI: $10.2174 / 1874149501610010719$

\title{
RETRACTION
}

\section{Retraction Notice: Perfectively Deducing Bessel Mean Square Error Formula}

Deng Yonghe $e^{* 1,2,3}$

${ }^{\prime}$ College of Engineering and designing, Lishui College, Lishui, Zhejiang, 323000, P.R. China

${ }^{2}$ School of Geodesy and Geomatics, Wuhan University, Wuhan 430079, P.R. China

${ }^{3}$ School of Continuous Education, Wuhan University, Wuhan 430079, P.R. China

\section{RETRACTION}

The Publisher and Editor have retracted this article [1] in accordance with good ethical practices. After thorough investigations we believe that the peer review process was compromised. The article was published online on 31-07-2015.

\section{REFERENCE}

[1] D. Yonghe, "Perfectively deducing bessel mean square error formula", Open Civ. Eng. J., vol. 9, pp. 423-425, 2015. 